\title{
Dietary intake of folate by adolescents and the potential effect of flour fortification with folic acid
}

\author{
P. J. Moynihan*, A. J. Rugg-Gunn, T. J. Butler and A. J. Adamson \\ The Dental School, and the Human Nutrition Research Centre, University of Newcastle, Newcastle upon Tyne, UK
}

(Received 11 September 2000 - Revised 9 May 2001 - Accepted 27 May 2001)

\begin{abstract}
The UK Department of Health recently recommended that flour be fortified with folic acid, at $2400 \mu \mathrm{g} / \mathrm{kg}$. The objectives of the present paper were: to determine the consequence of this on folic acid intake of adolescents; to determine the level of fortification necessary to achieve an intake of $400 \mu \mathrm{g} / \mathrm{d}$ in adolescent girls (the amount recommended periconceptionally); to estimate the consequence of fortification on folic acid intake of high flour consumers; and to report on folate intake of adolescents. Dietary intake of folate and flour were determined by analysis of an existing database of the diets of 379 English adolescents. The folic acid intake that would result from white flour fortification with folic acid at $2400 \mu \mathrm{g} / \mathrm{kg}$ was determined and the level of folic acid fortification necessary to achieve an intake of $400 \mu \mathrm{g} / \mathrm{d}$ in girls from this source was also calculated. Without flour fortification, $6.9 \%$ of girls failed to reach the UK lower reference nutrient intake for total folate. Fortification of white flour with folic acid at $2400 \mu \mathrm{g} / \mathrm{kg}$ would result in an additional folic acid intake of 191(SEM 6) $\mu \mathrm{g} / \mathrm{d}$ in girls. To ensure $97 \%$ of girls received $400 \mu \mathrm{g} / \mathrm{d}$ from white flour, white flour would need to be fortified at a level of $10430 \mu \mathrm{g} / \mathrm{kg}$, resulting in intakes of $1260 \mu \mathrm{g} / \mathrm{d}$ from flour in the highest (97.5 centile) female white flour consumers and $1422 \mu \mathrm{g} / \mathrm{d}$ from flour in the highest ( 97.5 centile) male white flour consumers.
\end{abstract}

Folic acid fortification of flour: Dietary total folate: Dietary flour intake: Adolescents

The UK has one of the highest rates of neural tube defects in the world (Medical Research Council Vitamin Study Research Group, 1991), affecting 1-2 per 1000 pregnancies. The role of folic acid in the prevention of neural tube defects has been well documented; it is estimated that a supplementary intake of $400 \mu \mathrm{g} / \mathrm{d}$ reduces the occurrence of neural tube defects by at least $50 \%$ (Laurence et al. 1981; Medical Research Council Vitamin Study Research Group, 1991; Czeizel \& Dudas, 1992; Kirke et al. 1992). In 1992, the UK Department of Health recommended those women planning to become pregnant and those in the early stages of pregnancy take a $400 \mu \mathrm{g}$ folic acid supplement/d to prevent neural tube defects (Department of Health, 1992). The success of this public health measure relies on communication of the recommendation, compliance with supplementation and on pregnancy being planned. Awareness of the benefits of folic acid supplementation is low amongst young women, compliance to the recommendation is poor and pregnancy is often not planned, particularly in young women (Clark \& Fisk, 1994; Wild et al. 1996).
In addition to the prevention of neural tube defects, folic acid has other potential health benefits. There is some evidence to show that plasma homocysteine levels are associated with cardiovascular disease (Boushey et al. 1995; Danesh \& Lewington, 1998). Folic acid supplementation can reduce plasma homocysteine levels, which suggests a potential protective role for folic acid in the prevention of cardiovascular disease (Malinow et al. 1998). In the USA, cereals and grain products have been fortified with folic acid since 1996 and there is some evidence that this has resulted in improved folate status (Jacques et al. 1999; Lawrence et al. 1999) and reduced homocysteine concentrations (Jacques et al. 1999). The Department of Health Committee on Medical Aspects of Food Policy (COMA) report Folic Acid and the Prevention of Disease (Department of Health, 2000) concluded that the fortification of food with folic acid would lower plasma homocysteine concentrations in some sections of the general population and that this might lower the incidence of cardiovascular disease. However, it was concluded that at present there is insufficient

\footnotetext{
Abbreviation: COMA, Committee on Medical Aspects of Food Policy.

* Corresponding author: Dr Paula J. Moynihan, fax +44 191222 5928, email p.j.moynihan@ncl.ac.uk
} 
evidence to advocate fortification solely on the aim of reducing cardiovascular disease.

There are some epidemiological data that suggest a low intake of folate may be associated with increased risk of cancer of the colon: in a longitudinal study, those who took multivitamin preparations containing folic acid were at lower risk of colon cancer (Giovanucci et al. 1998). However, at present there is insufficient evidence to show a specific link between folic acid and colon cancer.

The term 'folate' is a generic term that includes synthetic folic acid (pteroylglutamic acid) and its derivatives, such as the natural folates that occur in foods. Pteroylglutamic acid is absorbed and transformed into other folates. Folic acid is more stable and bioavailable than natural folates and is therefore the preferred folate to use for food fortification.

The Department of Health COMA has recently recommended that in the UK flour is fortified with folic acid at a level of $2400 \mu \mathrm{g} / \mathrm{kg}$ flour (Department of Health, 2000). Fortification is a relatively simple measure that would have a large effect in the prevention of a disabilitating neurological impairment. One of the concerns with fortification is that people who consume low amounts of flour-based products must consume sufficient to benefit, whereas those with high intakes of flour-based foods must not receive harmful amounts. The recent COMA report (Department of Health, 2000) provides an estimate of intake of folic acid from flour fortification with folic acid at $2400 \mu \mathrm{g} / \mathrm{kg}$ based on estimates of flour content of food groups. However, no analysis based on the flour content of individual foods and the mean and range of flour intakes by children have been reported. Information on the intake of flour from all sources, for different subgroups of the population, is therefore needed to determine the impact of COMA's recommendation.

The present paper presents analysis of existing data on the diets of English adolescents and reports on the intake of white flour and total folate. Detailed information on the white flour content of foods in McCance and Widdowson's The Composition of Foods (Paul \& Southgate, 1978) was available from earlier analysis with respect to calcium carbonate fortification of flour (Moynihan et al. 1996). From data on white flour intake, the impact of fortification of white flour with folic acid at $2400 \mu \mathrm{g} / \mathrm{kg}$ on the intake of folic acid from this source is determined. The level of flour folic acid fortification that would be needed to achieve an intake of $400 \mu \mathrm{g} / \mathrm{d}$ from this source is also determined. The aims of the present paper are:

(1) to provide information on the levels of flour intake by English adolescents;

(2) to report on total folate intake by adolescents;

(3) to calculate the impact of fortification of white flour with folic acid (at $2400 \mu \mathrm{g} / \mathrm{kg}$ ) on the folic acid intake (from fortification) by adolescents;

(4) to calculate the consequences of this in terms of total folate intake by adolescents;

(5) to calculate the level of white flour fortification with folic acid required to achieve an intake from this source of $400 \mu \mathrm{g} / \mathrm{d}$ in $97.5 \%$ of girls;

(6) to calculate the consequences of this in terms of additional folic acid intake by the highest white flour consumers.

\section{Methods}

In 1990, a dietary survey of 379 schoolchildren aged 11-12 years was carried out in Northumberland, UK. The method and main findings of this survey have been published previously (Adamson et al. 1992). Briefly, each child recorded all food and drink consumed on three consecutive days on two separate occasions. Computerised food tables together with purpose-written programs were used to calculate the mean daily total folate intake (Paul \& Southgate, 1978; Tan et al. 1985; Holland et al. 1988, 1989). Using the occupation of the head of household (Register General, 1980), subjects were divided into three social class groups: social class groups I and II were labelled as 'high', social class III as 'middle' and social classes IV and $\mathrm{V}$ as 'low'.

Intake of flour was determined by recipe inspection and food dissection as previously described (Moynihan et al. 1996). The mean daily intake of flour $(\mathrm{g} / \mathrm{d})$ was multiplied by 2.4 to give the theoretical intake of folic acid $(\mu \mathrm{g} / \mathrm{d})$ from flour fortification at $2400 \mu \mathrm{g} / \mathrm{kg}$. In addition, the resulting values were also added to the value obtained for dietary total folate intake.

Based on the distribution of values for flour intake calculations were carried out to determine the level of white flour fortification with folic acid required to ensure that $97.5 \%$ of girls would receive at least $400 \mu \mathrm{g}$ folic acid/d from white flour. The consequence of this level of fortification on the average additional folic acid intake of the adolescents from this source, and the additional folic acid intake of the highest $2.5 \%$ of flour consumers, was calculated.

Since the mean intake of flour for each subject was based on only a small number of days, the observed distribution of intakes was more variable than the true one. By estimating components of variance the reliability $(R)$ of the individual children's means could be calculated (Dunn, 1989) and used to find the standard deviation for girls in the underlying distribution (Rugg-Gunn et al. 1987). This was carried out so that estimates of fortification levels were based on the true variance rather than the observed distribution. In an attempt to minimise the effect of distribution assumptions, the observed proportion $P_{\mathrm{obs}}$, falling in the lower or upper $2.5 \%$ of the population was adjusted, rather than fitting a particular distribution to all of the data. We assumed normality in the tails and obtained $P_{\text {cor }}=$ $\phi\left(\phi-1\left(P_{\mathrm{obs}}\right) / \sqrt{ } R\right)$ where $\phi$ is the cumulative normal distribution function. Typically, the size of the adjustment made is comparable with the standard error of the estimate of the proportion.

Analyses were carried out separately for each sex and by social class group. The level of significance of differences between sexes was tested using $t$ test and the statistical significance of social class trends was tested using ANOVA. Using observed uncorrected values for these calculations includes variation from between survey as well as between day. By using components of variance models, 
Table 1. Intake of flour and calculated intake of folic acid from flour fortification at $2400 \mu \mathrm{g} / \mathrm{kg}$ by 379 English adolescents by sex and social class group*

(Mean values with their standard errors)

\begin{tabular}{|c|c|c|c|c|c|c|}
\hline & \multirow[b]{2}{*}{ Social class group $†$} & \multirow[b]{2}{*}{$n$} & \multicolumn{2}{|c|}{$\begin{array}{l}\text { Flour intake } \\
(\mathrm{g} / \mathrm{d})\end{array}$} & \multicolumn{2}{|c|}{$\begin{array}{l}\text { Folic acid } \\
\text { from } \\
\text { fortification } \\
(\mu \mathrm{g} / \mathrm{d})\end{array}$} \\
\hline & & & Mean & SEM & Mean & SEM \\
\hline \multirow[t]{4}{*}{ Girls } & All & 195 & 80 & 2 & 191 & 6 \\
\hline & 1 & 67 & 79 & 4 & 189 & 10 \\
\hline & 2 & 60 & 81 & 4 & 193 & 9 \\
\hline & 3 & 38 & 80 & 4 & 192 & 10 \\
\hline \multirow[t]{4}{*}{ Boys } & All & 184 & 83 & 3 & 199 & 5 \\
\hline & 1 & 70 & 84 & 5 & 202 & 12 \\
\hline & 2 & 56 & 78 & 4 & 187 & 10 \\
\hline & 3 & 32 & 90 & 6 & 216 & 14 \\
\hline
\end{tabular}

* For details of subjects and procedures, see Adamson et al. (1992), Moynihan et al. (1996) and p. 530.

† Key to social class groupings: $1=$ social classes I and II, $2=$ social class III, 3 = social classes IV and V (social class classification was unreliable for twenty-six boys and thirty girls).

the between-children component of variance can be isolated and used for a more accurate estimate of variation between children (Moynihan et al. 1996).

\section{Results}

No statistically significant differences were found for flour intake between sex or social class groups (Table 1). Based on the white flour intake of this group of children, fortification of white flour at a level of $2400 \mu \mathrm{g} / \mathrm{kg}$ would result in mean additional intakes of 199 (SEM 5) $\mu \mathrm{g} / \mathrm{d}$ and 191 (SEM 6) $\mu \mathrm{g} / \mathrm{d}$ in boys and girls respectively (Table 1). At this level of fortification the lowest $2.5 \%$ of flour consumers would have additional folic acid intakes of $92 \mu \mathrm{g}$ and $71 \mu \mathrm{g}$ for girls and boys respectively and the highest $2.5 \%$ of flour

Table 2. Folic acid intake from flour if fortified at $10430 \mu \mathrm{g} / \mathrm{kg}$ of 379 English adolescents by sex and social class group* (Mean values with their standard errors)

\begin{tabular}{|c|c|c|c|c|}
\hline & \multirow[b]{2}{*}{ Social class group $\dagger$} & \multirow[b]{2}{*}{$n$} & \multicolumn{2}{|c|}{$\begin{array}{c}\text { Folic acid intake } \\
\text { from fortification } \\
\text { at } 10043 \mu \mathrm{g} / \mathrm{kg} \\
(\mu \mathrm{g} / \mathrm{d})\end{array}$} \\
\hline & & & Mean & SEM \\
\hline \multirow[t]{4}{*}{ Girls } & All & 195 & 831 & 23 \\
\hline & 1 & 67 & 820 & 45 \\
\hline & 2 & 60 & 842 & 41 \\
\hline & 3 & 38 & 835 & 45 \\
\hline \multirow[t]{4}{*}{ Boys } & All & 184 & 866 & 27 \\
\hline & 1 & 70 & 876 & 52 \\
\hline & 2 & 56 & 811 & 41 \\
\hline & 3 & 32 & 939 & 61 \\
\hline
\end{tabular}

* For details of subjects and procedures, see Adamson et al. (1992), Moynihan et al. (1996) and p. 530.

† Key to social class groupings: $1=$ social classes I and II, $2=$ social class III, $3=$ social classes IV and V (social class classification was unreliable for twenty-six boys and thirty girls).
Table 3. The intake of dietary total folate of adolescents by sex and social class group*

(Mean values with their standard errors)

\begin{tabular}{ccccr}
\hline & & & \multicolumn{2}{c}{$\begin{array}{c}\text { Total folate } \\
\text { intake from diet } \\
(\mu \mathrm{g} / \mathrm{d})\end{array}$} \\
\cline { 3 - 5 } & Social class groupt & $n$ & Mean & SEM \\
\hline Girls & All & 195 & 153 & $3 \cdot 4$ \\
& 1 & 67 & 160 & $6 \cdot 0$ \\
Boys & 2 & 60 & 147 & $5 \cdot 8$ \\
& 3 & 38 & 148 & $7 \cdot 4$ \\
& All & 184 & 166 & $4 \cdot 4$ \\
& 1 & 70 & 171 & $7 \cdot 5$ \\
& 2 & 56 & 173 & $8 \cdot 6$ \\
& 3 & 32 & 161 & $10 \cdot 4$ \\
\hline
\end{tabular}

* For details of subjects and procedures, see Adamson et al. (1992), Moynihan et al. (1996) and p. 530.

† Key to social class groupings: $1=$ social classes I and II, $2=$ social class III, $3=$ social classes IV and V (social class classification was unreliable for twenty-six boys and thirty girls).

consumers would have additional intakes of $290 \mu \mathrm{g}$ and $327 \mu \mathrm{g}$ for girls and boys respectively.

The level of fortification required to ensure that $97.5 \%$ of girls received $400 \mu \mathrm{g} / \mathrm{d}$ from this source is $10430 \mu \mathrm{g} / \mathrm{kg}$. This level of fortification would result in an average additional folic acid intake of $831 \mu \mathrm{g}$ and $866 \mu \mathrm{g} / \mathrm{d}$ for girls and boys respectively (Table 2). The top $2.5 \%$ of white flour consumers would have an additional folic acid intake of $1260 \mu \mathrm{g} / \mathrm{d}$ and $1422 \mu \mathrm{g} / \mathrm{d}$ for girls and boys respectively.

No statistically significant differences were found between social class groups for dietary folate intake, however, boys were found to have a higher mean daily intake compared with girls $(P=0.02)$ (Table 3$)$. The percentages of girls and boys who failed to achieve the UK lower reference nutrient intake of $100 \mu \mathrm{g} / \mathrm{d}$ (the amount only sufficient for $2.5 \%$ of a population; Department of Health, 1991) for total folate were $6.9 \%$ and $9.7 \%$ respectively. The percentage of children with intakes of total folate above the reference nutrient intake of $200 \mu \mathrm{g} / \mathrm{d}$ (the amount sufficient for $97.5 \%$ of a population; Department of Health, 1991) were $9 \cdot 1$ and $24.7 \%$ for girls and boys respectively. The theoretical average intake of total folate that would be achieved (from diet and white flour fortification) if white flour were fortified at a level of $2400 \mu \mathrm{g} / \mathrm{kg}$ would be 343 (SEM 6) $\mu \mathrm{g} / \mathrm{d}$ for girls and 365 (SEM 8) $\mu \mathrm{g} / \mathrm{d}$ for boys. At this level of fortification, all subjects would have total folate intakes greater than the UK lower reference nutrient intake of $100 \mu \mathrm{g} / \mathrm{d}$.

\section{Discussion}

The present paper has reported the mean intake of white flour by adolescent English school children to be $80 \mathrm{~g} / \mathrm{d}$ and $83 \mathrm{~g} / \mathrm{d}$ for girls and boys respectively, and that fortification of white flour with folic acid at a level of $2400 \mu \mathrm{g} / \mathrm{kg}$ would result in intakes of folic acid from this source of approximately $200 \mu \mathrm{g} / \mathrm{d}$. This level of additional folic acid intake would be associated with a $35 \%$ reduction in the 
incidence of neural tube defects (Department of Health, 2000). The level of flour fortification required to achieve an intake of $400 \mu \mathrm{g} / \mathrm{d}$ in $97.5 \%$ of 11 -12-year-old girls from this source is $10430 \mu \mathrm{g} / \mathrm{kg}$ white flour.

The UK Department of Health (2000) recommendation is for all flour to be fortified: the present analysis has considered white flour only, as detailed information on the wholemeal flour content of foods was not available. However, the children in this study consumed on average less than $20 \mathrm{~g}$ wholemeal bread/d and other sources of wholemeal flour were negligible. Fortification of wholemeal flour would add approximately $32 \mu \mathrm{g}$ folic acid/d (boys 31.9 , girls 33.9 ) to the estimates given in the present paper.

The value obtained in the present study for additional folic acid intake from fortification at $2400 \mu \mathrm{g} / \mathrm{kg}$ flour is remarkably similar to the estimate given in the COMA report for girls of the same age group $(188 \mu \mathrm{g} / \mathrm{d}$; Department of Health, 2000). The level of fortification that would achieve $400 \mu \mathrm{g} / \mathrm{d}$ (the supplementary amount recommended periconceptionally; Department of Health, 1992) is substantially higher than that recommended in the recent COMA report, and than levels of fortification currently practiced in other countries; in the USA and Canada, flour is fortified with folic acid at a level of $1400 \mu \mathrm{g} / \mathrm{kg}$ flour. However, the subjects in the present study were not yet of child-bearing age and intake of flourcontaining foods may increase with age. White flour intake did not differ significantly between sex and social classes and this may suggest that fortification would have a fairly uniform effect on total intake in a given age group.

Public health authorities may argue not to fortify foods because of possible toxic effects. However, the recent Department of Health COMA report (Department of Health, 2000) states that there are no convincing reports of evidence of adverse neurological effects at intakes below $2000 \mu \mathrm{g} / \mathrm{d}$ and suggests an arbitrary safe upper daily intake of $1000 \mu \mathrm{g} / \mathrm{d}$. Fortification at $240 \mu \mathrm{g} / \mathrm{d}$ would not suggest a dietary intake exceeding $1000 \mu \mathrm{g} / \mathrm{d}$ in any of the subjects in the present study. Fortification at $10430 \mu \mathrm{g} / \mathrm{kg}$ may result in intakes in excess of $2000 \mu \mathrm{g} / \mathrm{d}$ in the minority of boys. It may therefore not be possible to fortify flour at a level to guarantee $400 \mu \mathrm{g} / \mathrm{d}$ to all adolescent girls without exceeding the presumed 'safe' level of intake defined in the Department of Health report. The Medical Research Council Vitamin Study did not find adverse effects from folate supplementation at $4000 \mu \mathrm{g} / \mathrm{d}$ and Czeizel \& Dudas found no toxic effects from supplementation at $8000 \mu \mathrm{g} / \mathrm{d}$ (Medical Research Council Vitamin Study Research Group, 1991; Czeizel \& Dudas, 1992). These levels of supplementation are equivalent to $2 \cdot 7$ - and 5.5-fold the folic acid intakes from white flour that the highest flour consumers (based on the present study) would be exposed to even if white flour were fortified at $10430 \mu \mathrm{g} / \mathrm{kg}$. However, these studies did not aim to investigate the toxic effects of folic acid (pteroylglutamic acid). Folic acid is metabolized to methylfolate but this process is saturated at doses in the region of 266-400 $\mu \mathrm{g}$ pteroylglutamic acid (Lucock et al. 1989; Kelly et al. 1997). Fortification at high levels may therefore result in lifelong exposure to unmetabolized pteroylglutamic acid and more research is needed into the in vivo effects of unmetabolized non-native pteroylglutamic acid on folate-dependent enzymes as studies in vitro indicate that pteroylglutamic acid acts to inhibit certain enzymes including those associated with nucleotide biosynthesis (Lucock et al. 1989; Kelly et al. 1997).

Folate supplementation has been associated with reduced absorption of $\mathrm{Zn}$. Simmer et al. (1987) found that $350 \mu \mathrm{g}$ folate/d reduced the absorption of a high dose ( $25 \mathrm{mg}$ ) of $\mathrm{Zn}$. However, whether folate reduces $\mathrm{Zn}$ absorption at normal levels of dietary $\mathrm{Zn}$ intake (about $7 \mathrm{mg} / \mathrm{d}$ ) is unknown. Very high doses of folate supplementation $(75 \times$ reference nutrient intake) have also been associated with mood changes (Hunter et al. 1970). However, the dose used (15 mg/d) was over 10 -fold the estimated maximum folate intake from flour fortification, at $10430 \mu \mathrm{g} / \mathrm{kg}$, calculated in the present paper. There are concerns that high intakes of folic acid mask the anaemia of vitamin $\mathrm{B}_{12}$ deficiency and that this increases the risk of neurological disorders. However, folic acid fortification will not cause vitamin $B_{12}$ deficiency and vitamin $\mathrm{B}_{12}$ deficiency can be diagnosed without the presence of anaemia.

The mean dietary intake of total folate in girls was comparable with the estimated average requirement of $150 \mu \mathrm{g} / \mathrm{d}$ (the amount thought to be sufficient for $50 \%$ of a population; Department of Health, 1991). The UK dietary reference values are, however, relatively low compared with other countries such as the USA where the dietary reference intake for total folate is $400 \mu \mathrm{g} / \mathrm{d}$ (Institute of Medicine, 1998). The low intakes of dietary folate found in the present study further support the need for folate fortification to achieve adequate intake.

The values for intake of total folate are lower than previously published values for older children. Crawley (1993) reported the folate intake of UK 16- and 17-year-old adolescents. Mean intakes varied from 238 to $344 \mu \mathrm{g} / \mathrm{d}$. Wild et al. (1996) found that folate intake in young adults (aged 16-19 years) was above the reference nutrient intake. The present values are more comparable with published data for younger children. A mean daily intake of $165 \mu \mathrm{g} / \mathrm{d}$ was reported in children aged 7-8 years who consumed a moderate amount of breakfast cereal (Ruxton et al. 1996).

The dietary data presented here were collected in 1990, however, they provide the only data available on white flour intake by adolescents in the UK. The present paper reports data from one age group only. Adults are likely to consume larger amounts of flour, and therefore would receive higher intakes of folic acid if fortification were adopted.

The present study assessed dietary total folate using food tables that are the best available estimate of folate content at present. However, it is recognised that assessment of folic acid intake is difficult because of the variation in the bioavailability of natural folate and its degradation on storage and preparation of food. The study presents total folate and not folic acid equivalents in order to enable comparison with previous research and the Department of Health dietary reference values for folate which are presented as total folate (Department of Health, 1991).

The measurement of voluntary food intake is known to be problematic (Garrow, 1974), not only due to recording inaccuracies, but also because it is difficult to obtain a good estimate of an individuals average intake. The conclusions of the present study are based on a dietary survey of a large 
sample of Northumbrian children representing both sexes and across all social classes. However, the conclusions do not account for possible geographical variations in the intake of flour.

In the present study the $2 \times 3 \mathrm{~d}$ estimated food diary method was used to record food intake. We acknowledge that the estimate of between-child variance will contain a proportion of variance due to the dietary recording method, which is the case with all dietary surveys. Reporting inaccuracies are known to occur in food recording studies and reliability and validity are difficult to assess (Young \& Trulson, 1960). The validity and reliabilty of the $2 \times 3 \mathrm{~d}$ estimated food diary method used in this study have been previous discussed in detail by Hackett et al. (1983). Additional validation of data from this survey based on the ratio between estimated $\mathrm{BMR}$ and reported energy intake has been carried out (Adamson et al. 1992) and ratios obtained were not indicative of under-reporting and were compatible with normal active adolescents.

\section{Acknowledgements}

The authors wish to thank the Northumberland Health and Education Authorities, the schools, the children and their families for their considerable assistance. This study was supported by the MRC and Northern Regional Health Authority.

\section{References}

Adamson AJ, Rugg-Gunn AJ, Butler TJ, Appleton DR \& Hackett AF (1992) Nutritional intake height and weight of 11-12-yearold Northumbrian children in 1990 compared with information obtained in 1980. British Journal of Nutrition 68, 543-563.

Boushey CJ, Beresford SAA, Omenn GS \& Motulsky AG (1995) A quantitative assessment of plasma homocysteine as a risk factor for vascular disease. Journal of the American Medical Association 274, 1049-1057.

Clark NAC \& Fisk NM (1994) Compliance with the Department of Health recommendations: routine folate prophylaxis to prevent fetal neural tube defects. British Journal of Obstetrics and Gynaecology 101, 709-710.

Crawley HF (1993) The role of breakfast cereals in the diets of 1617 year-old teenagers in Britain. Journal of Human Nutrition and Dietetics 6, 205-216.

Czeizel AE \& Dudas I (1992) Prevention of first occurrence of neural tube defects by periconceptional vitamin supplementation. New England Journal of Medicine 327, 1832-1835.

Danesh J \& Lewington S (1998) Plasma homocysteine and coronary heart disease: systematic review of published epidemiological studies. Journal of Cardiovascular Risk 5, 229-232.

Department of Health (1991) Dietary Reference Values for Food Energy and Nutrients in the United Kingdom. Report on Health and Social Subjects no 41. London: H.M. Stationery Office.

Department of Health (1992) Folic Acid and the Prevention of Neural Tube Defect. London: H.M. Stationery Office.

Department of Health (2000) Folic Acid and the Prevention of Disease. Report on Health and Social Subjects no 50. London: H.M. Stationery Office.

Dunn G (1989) Design and Analysis of Reliability Studies. London: Edward Arnold.

Garrow JS (1974) Energy Balance and Obesity in Man, p. 47. London: North Holland Publishing Company Limited.
Giovanucci E, Stampfer MJ, Colditz GA, Hunter DJ, Fuchs C, Rosner BA, Speizer FE \& Willet WC (1998) Multivitamin use folate and colon cancer in women in the nurses' health study. Annals of International Medicine 129, 517-524.

Hackett AF, Rugg-Gunn AJ \& Appleton DR (1983) Use of a dietary diary and interview to estimate the food intake of children. Human Nutrition: Applied Nutrition 37, 293-300.

Holland B, Unwin ID \& Buss DH (1988) Cereals and Cereal Products. The Third Supplement to McCance and Widdowson's 'The Composition of Foods'. London: H.M. Stationery Office.

Holland B, Unwin ID \& Buss DH (1989) Milk and Milk Products. The Fourth Supplement to McCance and Widdowson's 'The Composition of Foods'. London: H.M. Stationery Office.

Hunter R, Barnes J, Oakeley HF \& Matthews DM (1970) Toxicity of folic acid given in pharmacological doses to healthy volunteers. Lancet 1, 61-62.

Institute of Medicine (1998) Dietary Reference Intakes: Folate, other B Vitamins and Choline. Washington, DC: National Academy Press.

Jacques PF, Selhub J, Bostom AG, Wilson PWF \& Rosenberg IH (1999) The effect of folic acid fortification on plasma folate and total homocysteine concentrations. New England Journal of Medicine 340, 1449-1454.

Kelly P, McPartlin J, Goggins M, Weir DG \& Scott JM (1997) Unmetabolised folic acid in serum: acute studies in subjects consuming fortified food and supplements. American Journal of Clinical Nutrition 65, 1790-1795.

Kirke PN, Daly LE \& Elwood JH (1992) A randomised trial of low dose folic acid to prevent neural tube defects. Archives of Diseases of Childhood 67, 1442-1446.

Laurence KM, James N, Miller MH, Tennent GB \& Campbell H (1981) Double-blinded randomised controlled trial of folate treatment before conception to prevent recurrence of neural tube defects. British Medical Journal 282, 1509-1511.

Lawrence JM, Petitti DB, Watkins M \& Umekubo MA (1999) Trends in serum folate after food fortification. Lancet 354, 915-916.

Lucock MD, Wild J, Smithells R \& Hartley R (1989) In vivo characterisation of the absorption and biotransformation of pteroylglutamin acid in man: A model for future studies. Biochemical Medicine and Metabolic Biology 42, 30-42.

Malinow MR, Duell PB, Hess DL, Anderson PH, Kruger WD, Phillipson BE, Glkuckman RA, Block PC \& Upson BM (1998) Reduction of plasma homocysteine levels by breakfast cereal fortified with folic acid in patients with coronary heart disease. New England Journal of Medicine 338, 1009-1015.

Medical Research Council Vitamin Study Research Group (1991) Prevention of neural tube defects: results of the MRC Vitamin Study. Lancet 338, 132-137.

Moynihan PJ, Adamson AJ, Rugg-Gunn AJ, Appleton DR \& Butler TJ (1996) Dietary sources of calcium and the contribution of flour fortification to total calcium intake in the diets of Northumbrian adolescents. British Journal of Nutrition $\mathbf{7 5}$, 495-505.

Paul AA \& Southgate DAT (1978) McCance and Widdowson's 'The Composition of Foods', 4th ed. London: H.M. Stationery Office.

Register General (1980) Classification of Occupations 1980. Office of Populations Censuses and Surveys. London: H.M. Stationery Office.

Rugg-Gunn AJ, Hackett AF, Appleton DR, Eastoe JE, Dowthwaite L \& Wright WG (1987) The water intake of 405 Northumbrian adolescents aged 12-14 years. British Dental Journal 162, 335-340.

Ruxton CHS, O’Sullivan KR, Kirk TR \& Belton NR (1996) The contribution of breakfast to the diets of a sample of 136 
primary-schoolchildren in Edinburgh. British Journal of Nutrition 75, 419-431.

Simmer K, Iles CA, James C \& Thompson RPH (1987) Are ironfolate supplements harmful? American Journal of Clinical Nutrition 45, 122-125.

Tan SP, Wenlock RW \& Buss DH (1985) Immigrant Foods. Second supplement to McCance and Widdowson's 'The Composition of Foods'. London: H.M. Stationery Office.
Wild J, Schorah CJ, Maude K \& Levene MI (1996) Folate intake in young women and their knowledge of pre-conceptional folate supplementation to prevent neural tube defects. European Journal of Obstetritics, Gynecology and Reproductive Biology 70, 185-189.

Young CM \& Trulson MF (1960) Methodology for dietary studies in epidemiological surveys II. Strengths and weaknesses of existing methods. American Journal of Public Health 50, 803. 